\title{
Data report: isotopic and elemental analyses of pore fluids and carbonates from Sites U1378 and U1380 drilled during CRISP-A Expeditions 334 and 344 in the middle slope offshore Costa Rica'
}

Collin Ruark, ${ }^{2}$ Marta E. Torres, ${ }^{2}$ Jesse Muratli, ${ }^{2}$ and Evan A. Solomon ${ }^{3}$

\section{Chapter contents}

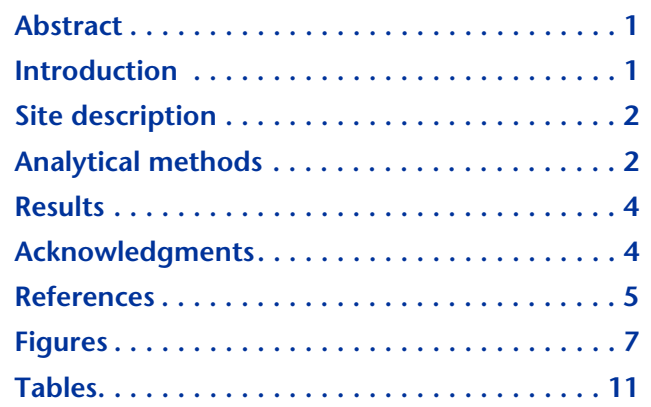

${ }^{1}$ Ruark, C., Torres, M.E., Muratli, J., and Solomon, E.A., 2019. Data report: isotopic and elemental analyses of pore fluids and carbonates from Sites U1378 and U1380 drilled during CRISP-A Expeditions 334 and 344 in the middle slope offshore Costa Rica. In Harris, R.N., Sakaguchi, A., Petronotis, K., and the Expedition 344 Scientists, Proceedings of the Integrated Ocean Drilling Program, 344: College Station, TX (Integrated Ocean Drilling Program).

doi:10.2204/iodp.proc.344.208.2019

${ }^{2}$ College of Earth, Ocean, and Atmospheric

Science, Oregon State University, 104 CEOAS

Administrative Building, Corvallis OR 97331-5503,

USA. Correspondence author:

mtorres@coas.oregonstate.edu

${ }^{3}$ School of Oceanography, University of

Washington, Seattle WA 98195, USA.

\section{Abstract}

Integrated Ocean Drilling Program (IODP) Sites U1378 and U1380, located in the middle slope off Costa Rica, were drilled to characterize the nature, composition, and physical properties of the margin. Drilling results from IODP Expeditions 334 and 344 revealed the material in the margin framework to be well lithified with calcite cemented horizons, which precluded the collection of pore fluids below the slope cover. We report on the elemental and isotopic composition of carbonate leached from cemented sediments underlying the slope cover and on the dissolved inorganic carbon and water isotopic composition of pore fluids in the slope cover. Molar ratios of $\mathrm{Sr} / \mathrm{Ca}(0.21-3.78 \mathrm{mmol} / \mathrm{mol}), \mathrm{Mn} / \mathrm{Ca}$ $(2.3-13.8 \mathrm{mmol} / \mathrm{mol})$, and $\mathrm{Ba} / \mathrm{Ca}(0.04-0.84 \mathrm{mmol} / \mathrm{mol})$ in the leached carbonate are shown relative to the pore water distribution of these elements. The ${ }^{87} \mathrm{Sr} /{ }^{86} \mathrm{Sr}$ ratios in carbonate range from 0.70797 to 0.70899 . Such nonradiogenic values are consistent with previously published dissolved strontium isotopes, which were attributed to a component of tephra alteration. Pore fluid $\delta^{13} \mathrm{C}$ values range from $-22.35 \%$ o to $10.88 \%$ referenced to Peedee belemnite (PDB), with a marked depletion in ${ }^{13} \mathrm{C}$ in the upper sediment $\left(\delta^{13} \mathrm{C}=-22.35 \%\right.$ PDB at 11.2 meters below seafloor [mbsf]) and enrichment in ${ }^{13} \mathrm{C}$ in the sediment section from 20.7 to 425.0 mbsf. Most carbonate samples have $\delta^{13} \mathrm{C}$ values in the range of $-2.62 \%$ to $0.24 \%$ PDB, and only three samples have $\delta^{13} \mathrm{C}$ values higher than $3.5 \%$ PDB. The $\delta^{18} \mathrm{O}$ of the carbonate samples ranges from $-6.35 \%$ to $2.31 \%$ PDB, and the $\delta^{18} \mathrm{O}$ of the water ranges from $-0.71 \%$ to $3.38 \%$ referenced to standard mean ocean water (SMOW).

\section{Introduction}

A primary objective of Integrated Ocean Drilling Program (IODP) Expeditions 334 and 344 was to understand the processes that generate earthquakes along the subduction plate boundary at erosive margins. Fundamental to this objective is determining the nature of the upper plate seaward of the seismogenic zone. Current models suggest that at erosive margins, such as those proposed for Costa Rica, fluids migrate from the plate interface and react little with the framework wedge material as they ascend and 
vent at the seafloor (e.g., Ranero and von Huene, 2000; Hensen et al., 2004; Sahling et al., 2008). Carbonate formation in the Costa Rica forearc was thus expected to result solely from anaerobic oxidation of the discharging methane-rich fluids, forming carbonate mounds that punctuate the margin. However, IODP drilling during the Costa Rica Seismogenesis Project (CRISP) revealed that significant fluidrock reactions occur in the margin framework, including extensive carbonate cementation at depth.

Here, we report on the chemical and isotopic composition of the carbonates recovered from Site U1380 and on isotopic composition of the dissolved inorganic carbon and water at Site U1378, which may aid in unraveling fluid sources and the processes that led to formation of the carbonate cements in the wedge framework of the margin.

\section{Site description}

Sites U1378 and U1380 are located on the middle slope of the Costa Rica margin $\left(8^{\circ} 35.9980^{\prime} \mathrm{N}\right.$, $84^{\circ} 4.4037^{\prime} \mathrm{W}$ ) (Figure F1). The upper $560 \mathrm{~m}$ of the sediment section was sampled at Site U1378, and deeper penetration was achieved by drilling Site U1380. The sites lie above the unlocked portion of the plate boundary, as indicated by interplate earthquake relocation and geodetic measurements (LaFemina et al., 2009). The primary goal in choosing these sites was to investigate the nature, composition, and physical properties of the upper plate framework.

The sediments at Site U1378, dominantly composed of a monotonous sequence of silty clay to clay that alternates with widely interspersed centimeter-scale sandy layers, were divided into two main lithostratigraphic units (Figure F1C). Unit I (0-128 meters below seafloor [mbsf]) is composed of terrigenous silty clay with interbedded fining-upward sequences consisting of lithic sands. Unit II (128-514 mbsf) is predominantly well-consolidated terrigenous clayey silt that remains unlithified to 560 mbsf. This site was abandoned during Expedition 334 because the thick slope sediment package $(\sim 750 \mathrm{~m})$ prevented the drill from reaching the underlying basement rock of interest, whereas the thinner slope cover of Site U1380 provided easier access.

At Site U1380, the margin consists of a $\sim 550 \mathrm{~m}$ thick section of slope sediment (Unit I) overlying upper plate framework rock (Figure F1). Drilling in Hole U1380A during Expedition 334 was terminated at 482.4 mbsf; this site was revisited during Expedition 344, and penetration in Hole U1380C reached 797.4 mbsf. In Unit I, three sandstone-rich horizons were recovered with centimeter- to decimeter-thick sandy layers cemented with calcite. Unit II (553-772 mbsf) is visually defined by a relatively sharp lithologic change into greenish gray clayey siltstone with intercalated sandstone and conglomerate layers. In the upper $120 \mathrm{~m}$ of Unit II, occasional thin sandstone horizons are well lithified by calcite cement; however, most are poorly consolidated. Shells, shell fragments, and lithic fragments are abundant and conspicuous components in the sandstone. Below 564 mbsf, the sandstone layers are abundant and massive (as thick as $80 \mathrm{~cm}$ ), normally graded, and become thicker and coarser with depth. The siltstone, sandstone, and conglomerate layers are moderately well lithified by calcite cement. Toward the bottom of the sequence, rip-up siltstone clasts and fragmented (as large as $8 \mathrm{~cm}$ ) calcite-cemented breccia are more frequent. Siltstone and sandstone smear slides indicate that the dominant matrix composition is volcanogenic with sedimentary lithic fragments, along with common feldspar and glass. The tuff layers are highly altered. The biogenic components decline precipitously and are absent in the lowermost part of this unit. Unit III is a $29.44 \mathrm{~m}$ thick massive, welllithified, very dark greenish gray silty claystone with intercalated sandstone layers. The silty claystone contains common calcite-cemented horizons (Figure F1D). The matrix contains mostly terrigenous material dominated by lithic fragments and feldspar but is nearly devoid of biogenic material.

A major finding of these expeditions was that the margin wedge is composed of well-indurated, cemented clastic sediment (Expedition 334 Scientists, 2012a; Harris et al., 2013a; Bangs et al., 2011). The anomalous porosity profiles and conspicuous seismic reflectors in the margin wedge have now been attributed to the lithologic changes associated with cementation, which is pervasive throughout the $800 \mathrm{~m}$ drilled at this site (Expedition 334 Scientists, 2012a; Harris et al., 2013a).

\section{Analytical methods}

\section{Pore water analyses (carbon, oxygen, and hydrogen isotopes)}

Pore water extraction was conducted on board the $\mathrm{R} / \mathrm{V}$ JOIDES Resolution following the procedures described by Expedition 334 Scientists (2012b) and Harris et al. (2013b). The squeezed pore fluids were collected in precleaned, plastic syringes attached to the squeezing assembly and subsequently filtered through a $0.45 \mu \mathrm{m}$ Gelman polysulfone disposable filter. Samples collected for oxygen and hydrogen analyses were sealed in glass ampoules. Samples for 
isotopic composition of dissolved inorganic carbon (DIC) were collected in $2 \mathrm{~mL}$ glass vials and preserved with $10 \mu \mathrm{L}$ of saturated $\mathrm{HgCl}_{2}$.

Pore water oxygen and hydrogen stable isotopic compositions were measured at the University of Washington (USA) on a Picarro Cavity Ring-Down Spectrometer water analyzer (Model L2130-i). The data are reported in standard delta notation relative to Vienna standard mean ocean water (VSMOW). The precision of the $\delta^{18} \mathrm{O}$ and $\delta \mathrm{D}$ measurements based on repeated analyses of VSMOW and several in-house standards is better than $\pm 0.05 \%$ and $\pm 0.2 \%$, respectively.

The stable isotopic composition $\left(\delta^{13} \mathrm{C}\right)$ of the DIC was measured at Oregon State University (USA) using a GasBench II automated sampler interfaced to a gas source stable isotope mass spectrometer as described by Torres et al. (2005). The precision of the $\delta^{13} \mathrm{C}$ measurements based on replicate analyses of a $\mathrm{NaHCO}_{3}$ stock solution is better than $\pm 0.1 \%$. Instrument calibration was accomplished by comparison to National Institute of Standards and Technology (NIST)8544 limestone (also known as NBS-19) prepared using a Kiel-III online acid digestion device, which yields isotopic values of $-2.19 \%$ $\pm 0.06 \%$ for $\delta^{18} \mathrm{O}$ and $1.94 \% 0 \pm 0.02 \%$ for $\delta^{13} \mathrm{C}(N=25)$. These values compare well with certified values of $-2.20 \%$ and $1.95 \%$ for $\delta^{18} \mathrm{O}$ and $\delta^{13} \mathrm{C}$.

\section{Solid-phase analyses}

Carbonate samples from Hole U1380C were selected from the lithified sediments in Units II and III. The total $\mathrm{CaCO}_{3}$ content was measured on board the JOIDES Resolution using a UIC $5011 \mathrm{CO}_{2}$ coulometer, as described by Expedition 334 Scientists (2012b) and Harris et al. (2013b).

Two leaching procedures were compared in their effectiveness at maximizing carbonate leached (represented by fraction carbonate leached) while minimizing clay contamination (represented by a molar ratio of aluminum to calcium): a $4.4 \mathrm{M}$ acetic acid leach (henceforth referred to as the "hard" leach) and a buffered acetic acid leach (referred to as the "soft" leach).

For the hard leach approach (method of Joseph et al., 2012), $8 \mathrm{~mL}$ of $4.4 \mathrm{M}$ acetic acid was added to 10 $\mathrm{mg}$ of powdered sediment in Teflon vials (Savillex) and refluxed for $12 \mathrm{~h}$ at $70^{\circ} \mathrm{C}$. Samples were then sonicated and centrifuged, dried down, and redissolved in 3\% nitric acid (v/w) for analysis. The soft leach procedure uses a modified version of the buffered acetic acid leaching method outlined by Du et al. (2016). About $0.2 \mathrm{~g}$ of powdered sample was added to preleached $15 \mathrm{~mL}$ Falcon tubes to which
$6.5 \mathrm{~mL}$ ultrapure (resistivity $>18 \mathrm{M} \Omega$ ) water (Milli-Q water purification system; Millipore; USA) and 0.6 $\mathrm{mL}$ buffered acetic acid $(0.5 \mathrm{M}$ sodium acetate and $3.3 \mathrm{M}$ acetic acid in ultrapure water buffered to $\mathrm{pH} 4$ ) were added. The tubes were shaken on a rotary benchtop shaker for $3 \mathrm{~h}$, centrifuged for $10 \mathrm{~min}$ at $4000 \mathrm{rpm}$, and the leachate was decanted and filtered using $0.45 \mu \mathrm{m}$ filters into clean Teflon vials. These leached fractions were then dried down, refluxed for $1 \mathrm{~h}$ with $1 \mathrm{~mL}$ concentrated $\mathrm{HNO}_{3}$, dried down a second time, and refluxed for $1 \mathrm{~h}$ with $2 \mathrm{~mL}$ of $6 \mathrm{M} \mathrm{HNO}_{3}$.

\section{Elemental analysis of carbonate samples}

Major (Al, Ca, Fe, and $\mathrm{Mg}$ ) and minor (Ba, Mn, and $\mathrm{Sr}$ ) elements in carbonate were analyzed on an Ametek SPECTRO ARCOS inductively coupled plasmaoptical emission spectrometer at the W.M. Keck Collaboratory for Plasma Spectrometry at Oregon State University. Element concentrations are reported as a molar ratio to calcium. Experimental uncertainties reported are $2 \sigma$ errors based on the three replicate analyses performed by the instrument per sample tube. Detection limits were calculated by multiplying the standard deviation of the three blank measurements for each element by the corresponding t-value for a $99 \%$ confidence interval $(\mathrm{df}=2 ; t=6.965)$. This value was then regressed on the standard curve to give the detection limit in parts per million.

\section{Isotopic analyses of carbonate samples}

In preparation for strontium isotopic analysis, aliquots of the sediment leaches containing 200 ng Sr were loaded onto in-house made microcolumns containing $50 \mu \mathrm{L}$ of $\mathrm{Sr}$ spec $100-150 \mu \mathrm{m}$ resin from Eichrom. The Sr fractions were subsequently diluted 50/50 with $3 \% \mathrm{HNO}_{3}$, and the isotopic analysis was performed using a Nu Plasma multicollector inductively coupled plasma-mass spectrometer at the W.M. Keck Collaboratory for Plasma Spectrometry. The ${ }^{87} \mathrm{Sr} /{ }^{86} \mathrm{Sr}$ ratios were doubly corrected: once by using the intraelemental correction for mass fractionation $\left({ }^{86} \mathrm{Sr} /{ }^{88} \mathrm{Sr}=0.1194\right)$ and again by internally normalizing the ratios to NIST standard NBS-987, with repeated measurements yielding a ${ }^{87} \mathrm{Sr} /{ }^{86} \mathrm{Sr}$ ratio of $0.701245 \pm 0.000027\left(2 \sigma_{\text {mean }} ; N=115\right)$. Instrument precision was determined through replicate analysis of an in-house standard with a measured ${ }^{87} \mathrm{Sr} /{ }^{86} \mathrm{Sr}$ ratio of $0.708183 \pm 0.000028\left(2 \sigma_{\text {mean }} ; N=100\right)$. These standards were run every six samples and in replicate at the beginning and end of every batch run.

Carbonate samples were isotopically characterized at Oregon State University using traditional phosphoric 
acid digestion and isotope ratio mass spectrometry (IRMS). Carbonate powders were reacted with $100 \%$ phosphoric acid at $75^{\circ} \mathrm{C}$; and isotopic composition was measured using the Kiel III device connected to a Thermo Fisher 252 gas source mass spectrometer. Isotopic analyses with this technique yield a precision better than $\pm 0.1 \%$ and $0.2 \%$ for $\delta^{13} \mathrm{C}$ and $\delta^{18} \mathrm{O}$, respectively. Instrument calibration was accomplished by comparison to NBS- 19 .

\section{Results}

Results from the pore water analyses are listed in Table $\mathrm{T} 1$, and data from carbonate extractions are listed in Table T2. We compare results from the two different leaching approaches to determine the method from which a minimum amount of clay is removed so as to minimize the influence of clays in the strontium isotopic composition attributed to the carbonate phase. The soft leaching method was shown to be the more favorable method in terms of both clay contamination and fraction of $\mathrm{CaCO}_{3}$ leached. Aluminum leached was far greater for all samples using the hard leach method, whereas $\mathrm{CaCO}_{3}$ leached was greater for all samples when the soft leach method was employed (Figure F2). In both cases, the amount of strontium leached remained relatively consistent. All subsequent carbonate elemental and Sr isotope data reported here for Hole U1380C samples were obtained using the soft leaching procedure.

The elemental ( $\mathrm{Sr} / \mathrm{Ba}, \mathrm{Ba} / \mathrm{Ca}$, and $\mathrm{Mn} / \mathrm{Ca}$ ) and isotopic $\left({ }^{87} \mathrm{Sr} /{ }^{86} \mathrm{Sr}, \delta^{13} \mathrm{C}\right.$, and $\left.\delta^{18} \mathrm{O}\right)$ composition of carbonate samples is shown in Figure F3 (triangles); the downcore plots also include pore water data from Sites U1378 and U1380 (circles) for comparison; the oxygen and carbon isotope data are from this study, the cation data are from Harris et al. (2013c) and Torres et al. (2014), and dissolved strontium isotope data are from Ross et al. (2015).

Downhole ${ }^{87} \mathrm{Sr} /{ }^{86} \mathrm{Sr}$ values for the Hole U1380C carbonates range from 0.70797 to 0.70899 ; these values are lower than seawater and are consistent with pore water data. Several samples from 707 to 796 mbsf exhibit ${ }^{87} \mathrm{Sr} /{ }^{86} \mathrm{Sr}$ ratios in a narrow range, from 0.70854 to 0.70872 , departing from the decreasing trend of the other samples in that depth range. The strontium concentration in the leached carbonate ranges from 0.52 to $4.46 \mu \mathrm{mol} / \mathrm{g}$, corresponding to molar ratios with respect to calcium of $0.21-3.78 \mathrm{mmol} / \mathrm{mol}$. Barium and manganese concentrations range from 0.06 to $0.69 \mu \mathrm{mol} / \mathrm{g}$ and from 2.7 to $77.8 \mu \mathrm{mol} / \mathrm{g}$, respectively, which correspond to molar ratios to calcium that range from 0.04 to $0.84 \mathrm{mmol} / \mathrm{mol}$ and from 2.3 to $13.8 \mathrm{mmol} / \mathrm{mol}$ for barium and manganese, respectively. Although strontium concentrations generally show a slight decrease downcore, depth plots of $\mathrm{Ba} / \mathrm{Ca}$ and $\mathrm{Mn} / \mathrm{Ca}$ display no such trend.

DIC (Figure F3E) shows a strong depletion in ${ }^{13} \mathrm{C}$ with depth, reaching a low value of $-22.35 \%$ Peedee belemnite (PDB) at 12 mbsf. This minimum corresponds to the depth of the sulfate depletion and methane increase (not shown), indicative of ${ }^{13} \mathrm{C}$ depletion driven by anaerobic oxidation of methane, as documented by Expedition 334 Scientists (2012c). Below 12 mbsf, DIC is progressively enriched in ${ }^{13} \mathrm{C}$, reaching a $\delta^{13} \mathrm{C}$ highest value of $10.88 \%$ o PDB at 84 mbsf. All values above seawater from 20 to $350 \mathrm{mbsf}$ likely reflect residual DIC from methanogenesis. Most carbonate samples have $\delta^{13} \mathrm{C}$ values in the range of $-2.62 \%$ to $0.24 \%$ PDB, and only three samples (344-U1380C-41R-1, 50-52 cm; 42R-1, 30$31 \mathrm{~cm}$; and 52R-2, 67-68, cm) have values exceeding $3.5 \%$ PDB, which sets them apart from the relatively consistent trend of the others. These three samples (open triangles) also exhibit slightly higher $\mathrm{Mn} / \mathrm{Ca}$ ratios and a more radiogenic strontium signal but are unexceptional with respect to the other elemental and isotope data.

The $\delta^{18} \mathrm{O}$ composition of the carbonates shows a slight decreasing trend with depth, whereas pore water data show fairly constant values to 552 mbsf. The isotopic composition of pore water recovered from the squeezed sediment has oxygen values that range from $-0.71 \%$ o to $3.38 \%$ o standard mean ocean water (SMOW) in $\delta^{18} \mathrm{O}$ (Figure F3F), with only a few samples outside that range. The $\delta^{18} \mathrm{O}$ versus $\delta^{13} \mathrm{C}$ plot shown in Figure F4 illustrates the deviations in the isotopic composition of the carbonate relative to seawater (dashed lines) and the clear enrichment in ${ }^{13} \mathrm{C}$ in three of the samples.

\section{Acknowledgments}

We thank Andy Ungerer and Andy Ross for their assistance with the analyses of carbonate samples and Richard Berg for his assistance with the pore water oxygen and hydrogen stable isotope analyses. This research used samples and data provided by the Integrated Ocean Drilling Program (IODP), which is sponsored by the U.S. National Science Foundation and participating countries under IODP-Management International. We gratefully acknowledge the officers, crew, drilling personnel, and scientific parties of IODP Expeditions 334 and 344, whose diligent work ensured the success of the expedition and recovery of the samples used in this research. This research was funded by the U.S. Science Support Pro- 
gram (USSSP) postcruise research awards T334B11 and T344A11 (Expeditions 334 and 344) to M.E. Torres and National Science Foundation Award OCE1233587 and USSSP postexpedition activity awards (PEAs) to E.A. Solomon.

\section{References}

Bangs, N.L., McIntosh, K.D., Silver, E.A., Ranero, C.R., Kluesner, J.W., von Huene, R., Cavanaugh, S., Graf, S., Cameselle, A.L., Baracco, A.M., and Nuñez, E., 2011. Preliminary results of the CRISP 3D seismic experiment, offshore Costa Rica [presented at the 2011 American Geophysical Union Fall Meeting, San Francisco, CA, 5-9 December 2011]. (Abstract T21B-2341) http://abstractsearch.agu.org/meetings/2011/FM/T21B-2341.html

Du, J., Haley, B.A., and Mix, A.C., 2016. Neodymium isotopes in authigenic phases, bottom waters and detrital sediments in the Gulf of Alaska and their implications for paleo-circulation reconstruction. Geochimica et Cosmochimica Acta, 193:14-35.

https://doi.org/10.1016/j.gca.2016.08.005

Expedition 334 Scientists, 2012a. Expedition 334 summary. In Vannucchi, P., Ujiie, K., Stroncik, N., Malinverno, A., and the Expedition 334 Scientists, Proceedings of the Integrated Ocean Drilling Program, 334: Tokyo (Integrated Ocean Drilling Program Management International, Inc.).

https://doi.org/10.2204/iodp.proc.334.101.2012

Expedition 334 Scientists, 2012b. Methods. In Vannucchi, P., Ujiie, K., Stroncik, N., Malinverno, A., and the Expedition 334 Scientists, Proceedings of the Integrated Ocean Drilling Program, 334: Tokyo (Integrated Ocean Drilling Program Management International, Inc.). https://doi.org/10.2204/iodp.proc.334.102.2012

Expedition 334 Scientists, 2012c. Site U1380. In Vannucchi, P., Ujiie, K., Stroncik, N., Malinverno, A., and the Expedition 334 Scientists, Proceedings of the Integrated Ocean Drilling Program, 334: Tokyo (Integrated Ocean Drilling Program Management International, Inc.). https://doi.org/10.2204/iodp.proc.334.105.2012

Harris, R.N., Sakaguchi, A., Petronotis, K., Baxter, A.T., Berg, R., Burkett, A., Charpentier, D., Choi, J., Diz Ferreiro, P., Hamahashi, M., Hashimoto, Y., Heydolph, K., Jovane, L., Kastner, M., Kurz, W., Kutterolf, S.O., Li, Y., Malinverno, A., Martin, K.M., Millan, C., Nascimento, D.B., Saito, S., Sandoval Gutierrez, M.I., Screaton, E.J., Smith-Duque, C.E., Solomon, E.A., Straub, S.M., Tanikawa, W., Torres, M.E., Uchimura, H., Vannucchi, P., Yamamoto, Y., Yan, Q., and Zhao, X., 2013a. Expedition 344 summary. In Harris, R.N., Sakaguchi, A., Petronotis, K., and the Expedition 344 Scientists, Proceedings of the Integrated Ocean Drilling Program, 344: College Station, TX (Integrated Ocean Drilling Program). https://doi.org/10.2204/iodp.proc.344.101.2013

Harris, R.N., Sakaguchi, A., Petronotis, K., Baxter, A.T., Berg, R., Burkett, A., Charpentier, D., Choi, J., Diz Ferreiro, P., Hamahashi, M., Hashimoto, Y., Heydolph, K., Jovane, L., Kastner, M., Kurz, W., Kutterolf, S.O., Li, Y.,
Malinverno, A., Martin, K.M., Millan, C., Nascimento, D.B., Saito, S., Sandoval Gutierrez, M.I., Screaton, E.J., Smith-Duque, C.E., Solomon, E.A., Straub, S.M., Tanikawa, W., Torres, M.E., Uchimura, H., Vannucchi, P., Yamamoto, Y., Yan, Q., and Zhao, X., 2013b. Methods. In Harris, R.N., Sakaguchi, A., Petronotis, K., and the Expedition 344 Scientists, Proceedings of the Integrated Ocean Drilling Program, 344: College Station, TX (Integrated Ocean Drilling Program).

https://doi.org/10.2204/iodp.proc.344.102.2013

Harris, R.N., Sakaguchi, A., Petronotis, K., Baxter, A.T., Berg, R., Burkett, A., Charpentier, D., Choi, J., Diz Ferreiro, P., Hamahashi, M., Hashimoto, Y., Heydolph, K., Jovane, L., Kastner, M., Kurz, W., Kutterolf, S.O., Li, Y., Malinverno, A., Martin, K.M., Millan, C., Nascimento, D.B., Saito, S., Sandoval Gutierrez, M.I., Screaton, E.J., Smith-Duque, C.E., Solomon, E.A., Straub, S.M., Tanikawa, W., Torres, M.E., Uchimura, H., Vannucchi, P., Yamamoto, Y., Yan, Q., and Zhao, X., 2013c. Mid-slope Site U1380. In Harris, R.N., Sakaguchi, A., Petronotis, K., and the Expedition 344 Scientists, Proceedings of the Integrated Ocean Drilling Program, 344: College Station, TX (Integrated Ocean Drilling Program).

https://doi.org/10.2204/iodp.proc.344.106.2013

Hensen, C., Wallmann, K., Schmidt, M., Ranero, C.R., and Suess, E., 2004. Fluid expulsion related to mud extrusion off Costa Rica-a window to the subducting slab. Geology, 32(3):201-204.

https://doi.org/10.1130/G20119.1

Joseph, C., Torres, M.E., Martin, R.A., Haley, B.A., Pohlman, J.W., Riedel, M., and Rose, K., 2012. Using the ${ }^{87} \mathrm{Sr} /$ ${ }^{86} \mathrm{Sr}$ of modern and paleoseep carbonates from northern Cascadia to link modern fluid flow to the past. Chemical Geology, 334:122-130. https://doi.org/10.1016/j.chemgeo.2012.10.020

LaFemina, P., Dixon, T.H., Govers, R., Norabuena, E., Turner, H., Saballos, A., Mattioli, G., Protti, M., and Strauch, W., 2009. Fore-arc motion and Cocos Ridge collision in Central America. Geochemistry, Geophysics, Geosystems, 10(5):Q05S14.

https://doi.org/10.1029/2008GC002181

Ranero, C.R., and von Huene, R., 2000. Subduction erosion along the Middle America convergent margin. Nature, 404(6779):748-752. https://doi.org/10.1038/35008046

Ross, N., Torres, M.E., Haley, B.A., Solomon, E.A., and Kastner, M., 2015. Data report: strontium isotope analyses of pore fluids from the CRISP-A transect drilled during Expeditions 334 and 344. In Harris, R.N., Sakaguchi, A., Petronotis, K., and the Expedition 344 Scientists, Proceedings of the Integrated Ocean Drilling Program, 344: Tokyo (Integrated Ocean Drilling Program Management International, Inc.). https://doi.org/10.2204/iodp.proc.344.201.2015

Sahling, H., Masson, D.G., Ranero, C.R. Hühnerbach, V., Weinrebe, W., Klaucke, I., Bürk, D., Brückmann, W., and Suess, E., 2008. Fluid seepage at the continental margin offshore Costa Rica and southern Nicaragua. Geochemistry, Geophysics, Geosystems, 9(5):Q05S05.

https://doi.org/10.1029/2008GC001978 
Torres, M.E., Muratli, J.M., and Solomon, E.A., 2014. Data report: minor element concentrations in pore fluids from the CRISP-A transect drilled during Expedition 334. In Vannucchi, P., Ujiie, K., Stroncik, N., Malinverno, A., and the Expedition 334 Scientists, Proceedings of the Integrated Ocean Drilling Program, 334: Tokyo (Integrated Ocean Drilling Program Management Interna- tional, Inc.).

https://doi.org/10.2204/iodp.proc.334.201.2014

Initial receipt: 5 June 2018

Acceptance: 30 October 2018

Publication: 31 January 2019

MS 344-208 
Figure F1. A. Map of the region offshore Costa Rica targeted by the IODP CRISP program. B. Sites drilled during Expeditions 334 and 344, showing location of Sites U1378 and U1380 used in this study. C. Simplified lithologic column for Sites U1378 and U1380 drilled on the middle slope. D. Location of Sites U1378 and U1380 in seismic data. Both lithologic and seismic data revealed a discontinuity between the upper sequences that correspond to slope sediment deposits and the underlying margin framework. The slope cover is $\sim 750 \mathrm{~m}$ thick at Site U1378, whereas the discontinuity between slope cover and underlying framework is at $550 \mathrm{mbsf}$ at Site U1380. E. Hole U1380C rocks from below $550 \mathrm{mbsf}$, described by Expedition 344 sedimentologists as calcitecemented clastic sediment (344-U1380C-52R-2, 0.5-6.5 cm). From Expedition 334 Scientists (2012a) and Harris et al. (2013a).

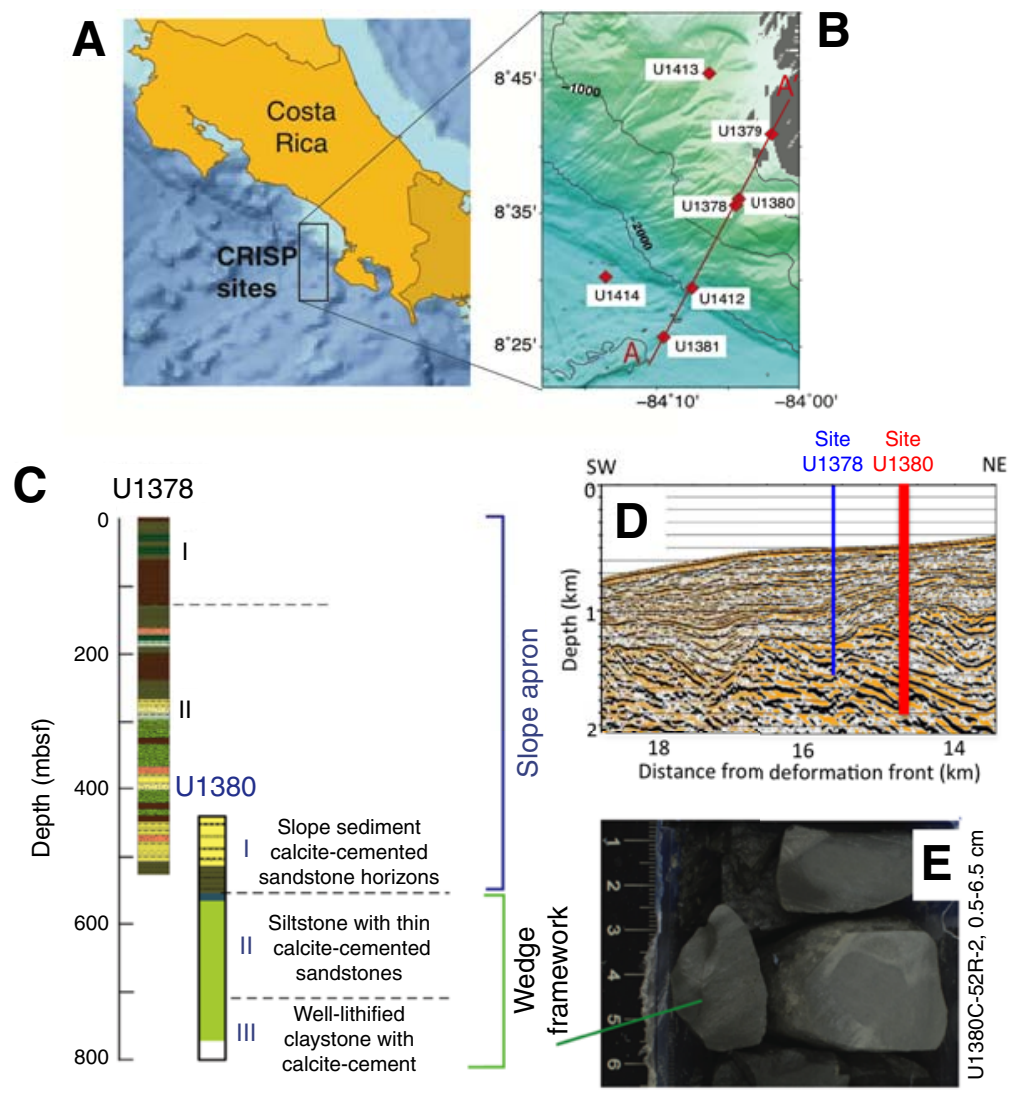


Figure F2. Results from hard (black) and soft (gray) sediment leaching procedures used to extract carbonate component from sediments, Hole U1380C. (A) $\mathrm{Al} / \mathrm{Ca}$, (B) fraction of $\mathrm{CaCO}_{3}$, and (C) Sr/Ca leached.
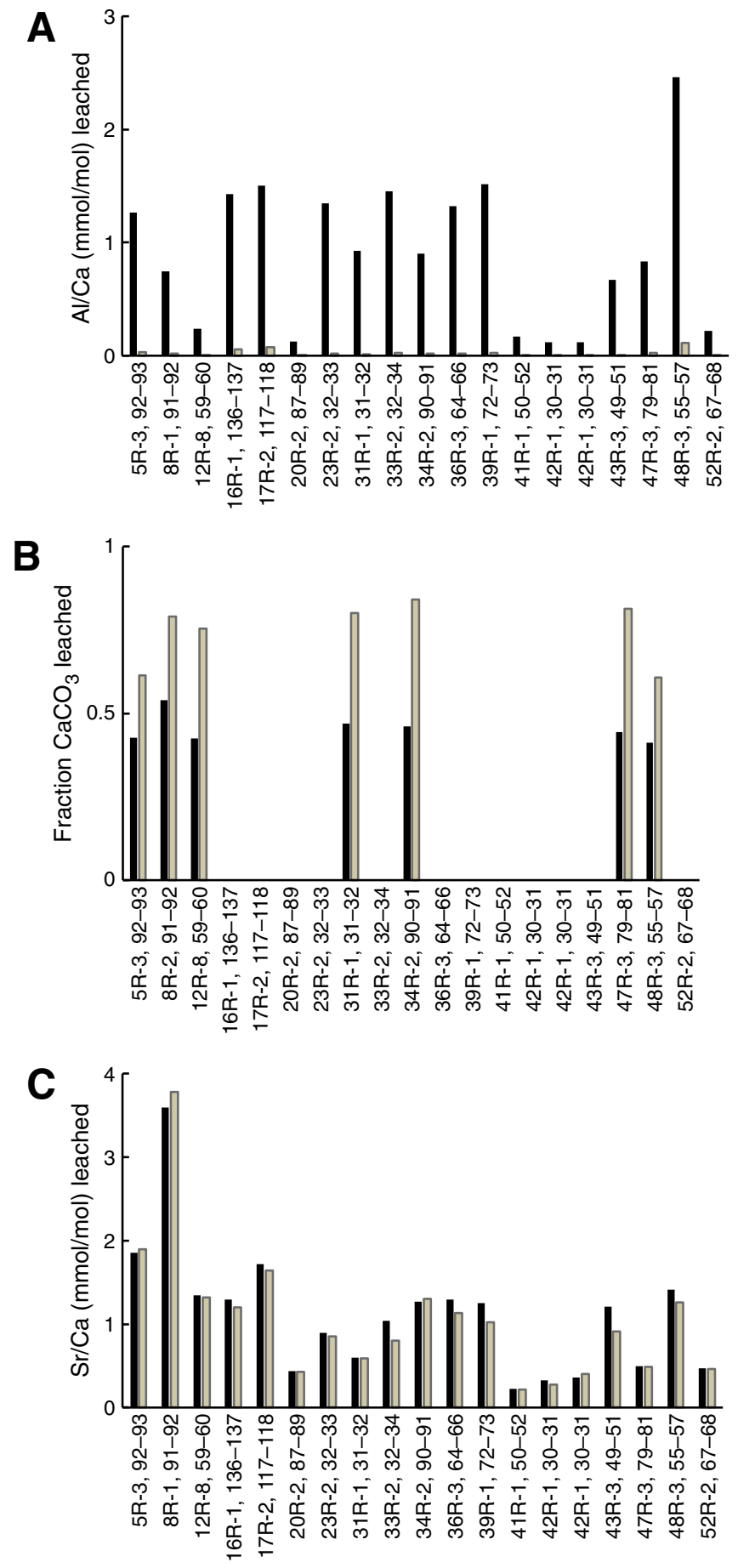
Figure F3. A. ${ }^{87} \mathrm{Sr} /{ }^{86} \mathrm{Sr}$ in Hole U1380C carbonates (triangles) compared with ratios in pore fluids reported by Ross et al. (2015) (blue circles = Hole U1378B, green circles = Hole U1380C). B-D. Elemental composition of Hole U1380C carbonate samples (triangles) from soft leaching procedure compared with published pore water composition of fluids from Hole U1378B (blue circles) and Holes U1380A and U1380C (green circles) (Harris et al., 2013c; Torres et al., 2014). E-F. Downcore profiles of $\delta^{13} \mathrm{C}$ and $\delta^{18} \mathrm{O}$ in Hole U1380C carbonates (triangles) and corresponding pore water isotopic data for DIC and water for Holes U1378B (blue circles) and U1380C (green circles). Open triangles represent samples with heavier carbon isotopic values relative to the other carbonates (344-U1380C-41R-1, 50-52 cm; 42R-1, 30-31 cm; and 52R-2, 67-68 cm).
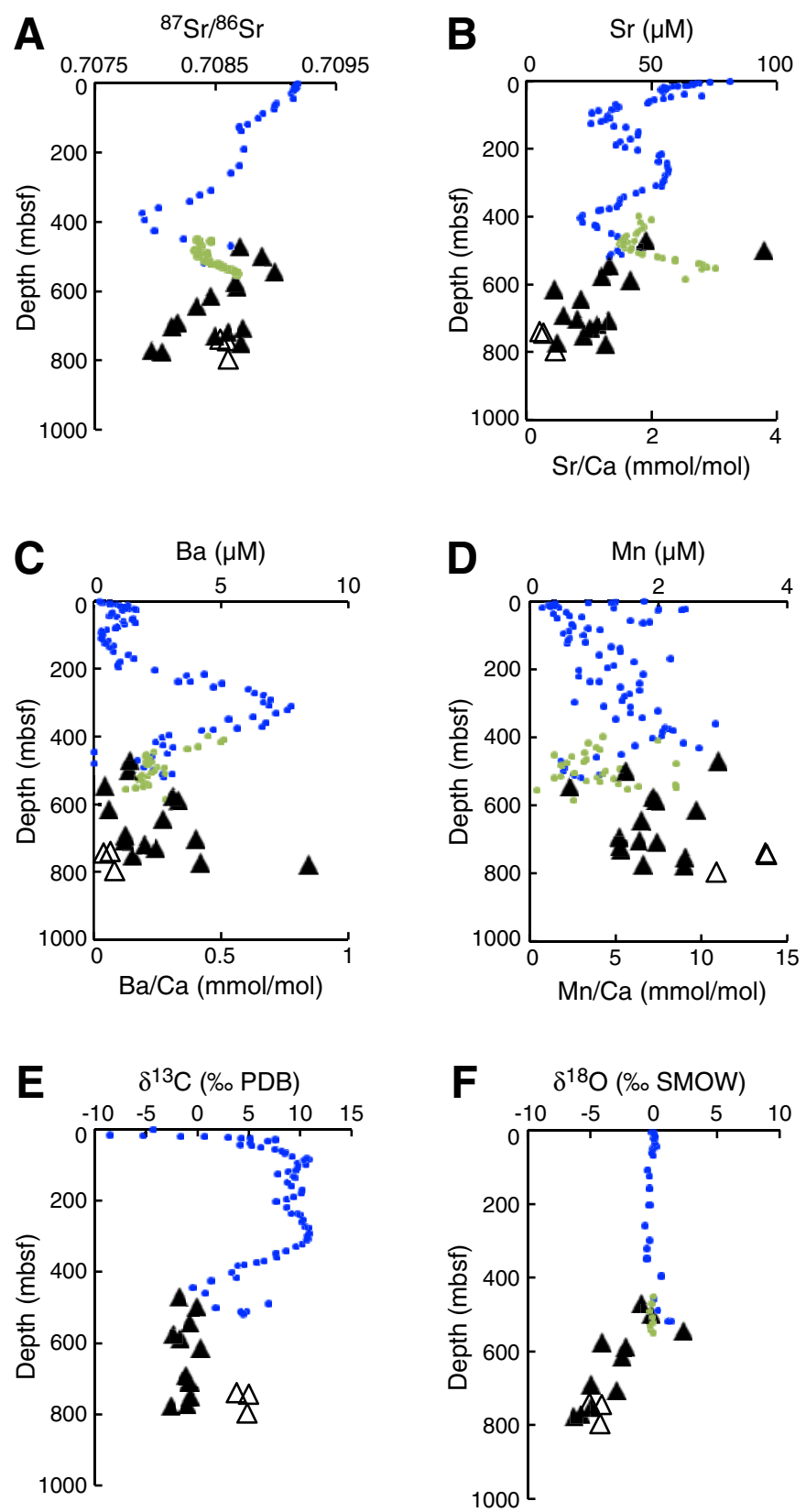
Figure F4. Plot of $\delta^{18} \mathrm{O}$ vs. $\delta^{13} \mathrm{C}$ for Hole U1380C carbonates. Open triangles represent samples with heavier isotopic carbon signatures when compared with the other carbonates (344-U1380C-41R-1, 50-52 cm; 42R-1, 30$31 \mathrm{~cm}$; and 52R-2, 67-68 cm).

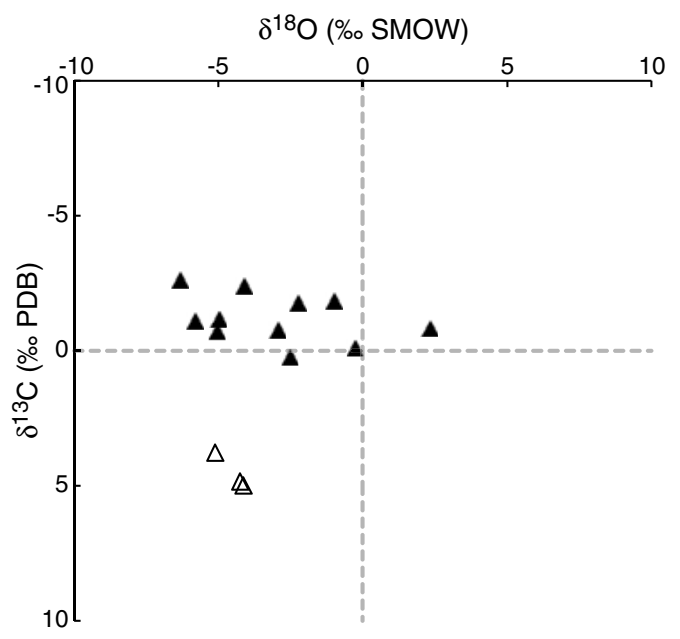


Table T1. Pore fluid geochemical data, Holes U1378B and U1380C. (Continued on next page.)

\begin{tabular}{|c|c|c|c|c|c|}
\hline $\begin{array}{l}\text { Core, section, } \\
\text { interval }(\mathrm{cm})\end{array}$ & $\begin{array}{l}\text { Depth } \\
\text { (mbsf) }\end{array}$ & $\begin{array}{c}\delta^{13} \mathrm{C} \\
(\% \circ \mathrm{PDB})\end{array}$ & $\begin{array}{c}\delta^{18} \mathrm{O} \\
(\% \text { SMOW) }\end{array}$ & $\begin{array}{c}\delta \mathrm{D} \\
\text { (\%o SMOW) }\end{array}$ & ${ }^{87} \mathrm{Sr} /{ }^{86} \mathrm{Sr}$ \\
\hline \multicolumn{6}{|l|}{ 334-U1378B- } \\
\hline $1 \mathrm{H}-1,138-168$ & 1.38 & -4.34 & & & 0.70918 \\
\hline $1 \mathrm{H}-2,138-168$ & 2.88 & -12.74 & & & 0.70917 \\
\hline $1 \mathrm{H}-3,138-168$ & 4.38 & -10.76 & & & \\
\hline $1 \mathrm{H}-4,46-58$ & 4.96 & -14.12 & & & 0.70916 \\
\hline $2 \mathrm{H}-1,138-168$ & 6.68 & -15.45 & -0.03 & 0.98 & \\
\hline $2 \mathrm{H}-1,138-168^{*}$ & 6.68 & & -0.22 & 2.75 & \\
\hline $2 \mathrm{H}-2,138-150$ & 8.18 & -18.62 & & & \\
\hline $2 \mathrm{H}-3,138-168$ & 9.68 & -19.85 & & & 0.70915 \\
\hline $2 \mathrm{H}-4,138-168$ & 11.18 & -22.35 & & & 0.70916 \\
\hline $2 \mathrm{H}-5,138-150$ & 12.68 & -21.91 & & & \\
\hline $2 \mathrm{H}-6,138-150$ & 14.18 & -16.45 & & & 0.70917 \\
\hline $2 \mathrm{H}-7,54-66$ & 14.84 & -14.08 & & & \\
\hline $3 \mathrm{H}-1,138-150$ & 16.18 & -8.57 & & & 0.70916 \\
\hline $3 \mathrm{H}-2,138-150$ & 17.68 & -5.35 & 0.13 & 2.69 & \\
\hline $3 \mathrm{H}-3,138-148$ & 19.18 & -1.67 & & & 0.70914 \\
\hline $3 \mathrm{H}-4,138-148$ & 20.68 & 0.65 & & & \\
\hline $3 \mathrm{H}-5,138-148$ & 22.18 & 2.92 & & & \\
\hline $3 \mathrm{H}-6,133-143$ & 23.63 & 4.17 & 0.06 & 2.52 & \\
\hline $3 \mathrm{H}-6,133-143^{*}$ & 23.63 & & -0.06 & 3.49 & 0.70914 \\
\hline $3 \mathrm{H}-7,58-68$ & 24.38 & 5.08 & 0.06 & 2.81 & \\
\hline $4 \mathrm{H}-3,138-148$ & 27.79 & 7.52 & & & 0.70912 \\
\hline $4 \mathrm{H}-6,138-148$ & 32.29 & 6.77 & 0.05 & 3.42 & \\
\hline $5 \mathrm{H}-2,138-148$ & 36.68 & 5.05 & & & \\
\hline $5 \mathrm{H}-6,138-148$ & 42.68 & 4.11 & 0.22 & 3.83 & 0.70914 \\
\hline $6 \mathrm{H}-2,138-148$ & 46.18 & 5.25 & & & \\
\hline $6 \mathrm{H}-5,138-148$ & 50.68 & 6.13 & 0.06 & 4.45 & \\
\hline $6 \mathrm{H}-5,138-148^{*}$ & 50.68 & & -0.10 & 5.50 & \\
\hline 7H-2, 138-148 & 55.68 & 7.56 & & & 0.709 \\
\hline 7H-5, 138-148 & 60.18 & 8.12 & -0.17 & 3.40 & \\
\hline $8 \mathrm{H}-2,138-148$ & 63.82 & 8.6 & & & 0.70899 \\
\hline $8 \mathrm{H}-5,138-153$ & 68.32 & 8.49 & -0.09 & 3.73 & \\
\hline $9 \mathrm{H}-2,138-153$ & 74.68 & 9.19 & & & 0.70898 \\
\hline $9 \mathrm{H}-5,130-145$ & 79.10 & 10.54 & & & \\
\hline $10 \mathrm{H}-2,130-145$ & 84.10 & 10.88 & & & \\
\hline $10 \mathrm{H}-4,138-153$ & 87.10 & 10.27 & & & 0.70889 \\
\hline $11 \mathrm{H}-3,138-153$ & 93.98 & 9.69 & & & \\
\hline $12 \mathrm{H}-3,138-153$ & 99.83 & 10.47 & & & 0.70885 \\
\hline $13 \mathrm{H}-4,138-153$ & 107.88 & 9.7 & -0.46 & 2.99 & \\
\hline $13 \mathrm{H}-4,138-153^{*}$ & 107.88 & & -0.56 & 3.50 & \\
\hline $14 \mathrm{H}-3,138-153$ & 114.09 & 9.53 & & & \\
\hline $15 \mathrm{H}-2,118-133$ & 118.48 & 8.82 & & & 0.70876 \\
\hline $16 \mathrm{H}-3,133-148$ & 124.78 & 7.77 & -0.35 & 1.82 & 0.70869 \\
\hline $17 X-3,133-148$ & 132.13 & 9.32 & & & \\
\hline $18 X-3,113-128$ & 136.33 & 9.49 & & & 0.70871 \\
\hline $19 X-5,71-86$ & 148.55 & 8.73 & & & \\
\hline $20 X-5,130-145$ & 158.24 & & -0.36 & 2.20 & \\
\hline $20 X-5,130-145^{*}$ & 158.24 & 9.11 & -0.32 & 2.36 & \\
\hline $21 X-7,68-83$ & 169.64 & 10.12 & & & \\
\hline $22 X-5,88-103$ & 178.18 & 10.08 & & & \\
\hline $23 X-6,109-124$ & 188.79 & 9.33 & & & 0.70873 \\
\hline $24 X-4,122-137$ & 194.91 & 8.68 & & & \\
\hline $25 X-3,74-89$ & 202.69 & 7.59 & -0.22 & 1.85 & \\
\hline $25 X-3,74-89^{*}$ & 202.69 & & -0.43 & 1.98 & \\
\hline $27 X-2,100-115$ & 220.00 & 8.65 & & & \\
\hline $28 X-7,33-63$ & 236.43 & 9.07 & & & \\
\hline $29 X-3,45-80$ & 236.75 & 9.66 & & & 0.70869 \\
\hline $30 X-2,110-145$ & 240.90 & 9.97 & & & \\
\hline $31 X-4,118-148$ & 252.48 & 10.29 & & & \\
\hline $32 X-3,73-103$ & 259.83 & 10.11 & -0.71 & -0.36 & 0.70862 \\
\hline $33 X-5,58-93$ & 271.89 & 10.46 & & & \\
\hline $34 X-2,86-121$ & 277.96 & 10.79 & & & \\
\hline $35 X-5,98-133$ & 292.08 & 10.84 & & & \\
\hline $36 X-2,93-128$ & 297.63 & 10.65 & -0.33 & -0.39 & \\
\hline $37 X-2,91-126$ & 307.21 & 10.84 & & & 0.70846 \\
\hline $38 X-1,118-153$ & 310.48 & 10.58 & & & \\
\hline $39 X-5,118-153$ & 321.68 & 10.1 & -0.55 & -3.11 & 0.70836 \\
\hline $40 X-4,80-115$ & 329.10 & 9.57 & & & \\
\hline $41 X-5,104-139$ & 340.74 & 8.56 & & & 0.70828 \\
\hline
\end{tabular}


Table T1 (continued).

\begin{tabular}{|c|c|c|c|c|c|}
\hline $\begin{array}{l}\text { Core, section, } \\
\text { interval }(\mathrm{cm})\end{array}$ & $\begin{array}{l}\text { Depth } \\
\text { (mbsf) }\end{array}$ & $\begin{array}{c}\delta^{13} \mathrm{C} \\
(\% \circ \mathrm{PDB})\end{array}$ & $\begin{array}{c}\delta^{18} \mathrm{O} \\
(\% \text { SMOW) }\end{array}$ & $\begin{array}{c}\delta \mathrm{D} \\
(\% \text { SMOW) }\end{array}$ & ${ }^{87} \mathrm{Sr} /{ }^{86} \mathrm{Sr}$ \\
\hline $42 X-3,64-94$ & 347.04 & 7.63 & -0.46 & -2.91 & \\
\hline $42 X-3,64-94^{*}$ & 347.04 & & -0.58 & -2.50 & \\
\hline $43 X-5,55-85$ & 358.71 & 7.68 & & & 0.70802 \\
\hline $45 X-3,55-85$ & 369.65 & 6.44 & & & \\
\hline $46 X-2,115-145$ & 374.25 & 5.77 & & & 0.70789 \\
\hline $47 X-2,95-125$ & 379.35 & 4.45 & & & \\
\hline $48 X-1,96-121$ & 382.86 & 3.88 & & & \\
\hline $49 X-3,106-136$ & 394.66 & & 0.59 & -3.03 & 0.70791 \\
\hline $49 \times-3,106-136^{*}$ & 394.66 & & 0.56 & -1.97 & \\
\hline $50 X-2,97-127$ & 402.27 & 3.31 & & & \\
\hline $51 X-5,85-115$ & 415.96 & 3.72 & & & \\
\hline $52 X-5,70-100$ & 425.00 & 1.29 & & & 0.70799 \\
\hline $54 X-5,104-140$ & 444.24 & -0.53 & & & \\
\hline $55 X-2,81-116$ & 448.81 & & & & 0.70823 \\
\hline $56 X-2,64-99$ & 458.24 & 0.7 & -0.02 & -4.65 & \\
\hline $57 X-3,63-98$ & 469.33 & & & & 0.70862 \\
\hline $58 X-2,90-126$ & 478.26 & & & & \\
\hline $59 X-4,93-128$ & 489.66 & 6.83 & 0.30 & -5.17 & \\
\hline $60 X-4,60-95$ & 499.72 & 1.76 & & & \\
\hline $61 X-4,102-137$ & 510.12 & 4.16 & & & 0.70844 \\
\hline $62 X-1,54-79$ & 510.24 & 4.8 & & & 0.7084 \\
\hline $63 X-4,84-119$ & 518.74 & 4.39 & 1.36 & -5.37 & \\
\hline $63 X-4,84-119 *$ & 518.74 & & 1.07 & -4.22 & 0.7084 \\
\hline \multicolumn{6}{|l|}{ 344-U1380C- } \\
\hline 3R-3, 114-144 & 451.94 & & -0.06 & -6.42 & 0.70834 \\
\hline $3 R-5,112-150$ & 454.70 & & & & 0.70846 \\
\hline $4 R-1,51-73$ & 458.13 & & & & 0.70836 \\
\hline $5 R-3,107-137$ & 470.67 & & -0.21 & -6.57 & 0.70838 \\
\hline $6 \mathrm{R}-3,122-152$ & 481.25 & & & & 0.70833 \\
\hline $7 R-3,120-150$ & 491.00 & & -0.40 & -6.05 & 0.70842 \\
\hline 7R-5, 87-107 & 493.40 & & & & 0.70837 \\
\hline $8 R-2,116-146$ & 499.12 & & & & 0.70835 \\
\hline $9 R-1,102-132$ & 507.22 & & -0.11 & -6.97 & 0.70844 \\
\hline 9R-6, 79-109 & 513.28 & & & & 0.70841 \\
\hline $10 R-4,53-78$ & 519.53 & & & & 0.70846 \\
\hline 10R-6, 64-90 & 521.93 & & -0.05 & -7.67 & 0.70851 \\
\hline $11 \mathrm{R}-2,59-89$ & 526.87 & & & & 0.70854 \\
\hline $11 R-4,87-117$ & 529.54 & & -0.33 & -8.18 & 0.70856 \\
\hline $12 \mathrm{R}-2,79-113$ & 537.55 & & & & 0.7086 \\
\hline $12 R-4,78-108$ & 539.58 & & -0.26 & -7.81 & 0.70864 \\
\hline $12 \mathrm{R}-8,62-92$ & 543.72 & & & & 0.70867 \\
\hline $13 R-3,50-80$ & 548.02 & & -0.09 & -6.81 & 0.70868 \\
\hline $13 R-6,58-88$ & 551.90 & & -0.06 & -7.78 & 0.70868 \\
\hline
\end{tabular}

* = duplicate sample. ${ }^{87} \mathrm{Sr} /{ }^{86} \mathrm{Sr}$ data normalized to NIST standard NBS-987 (Ross et al., 2015). PDB = Peedee belemnite, SMOW = standard mean ocean water. 
Table T2. Carbonate geochemical data, Hole U1380C.

\begin{tabular}{|c|c|c|c|c|c|c|c|c|c|}
\hline $\begin{array}{l}\text { Core, section, } \\
\text { interval }(\mathrm{cm})\end{array}$ & $\begin{array}{l}\text { Depth } \\
\text { (mbsf) }\end{array}$ & $\begin{array}{l}\mathrm{CaCO}_{3} \\
\text { (wt\%) }\end{array}$ & $\begin{array}{c}\text { Fraction } \\
\mathrm{CaCO}_{3} \\
\text { leached }\end{array}$ & $\begin{array}{c}\delta^{13} \mathrm{C} \\
(\% \circ \mathrm{PDB})\end{array}$ & $\begin{array}{c}\delta^{18} \mathrm{O} \\
(\% \text { SMOW) }\end{array}$ & ${ }^{87} \mathrm{Sr} /{ }^{86} \mathrm{Sr}$ & $\begin{array}{c}\mathrm{Ba} / \mathrm{Ca} \\
(\mathrm{mmol} / \mathrm{mol})\end{array}$ & $\begin{array}{c}\mathrm{Mn} / \mathrm{Ca} \\
(\mathrm{mmol} / \mathrm{mol})\end{array}$ & $\begin{array}{c}\mathrm{Sr} / \mathrm{Ca} \\
(\mathrm{mmol} / \mathrm{mol})\end{array}$ \\
\hline \multicolumn{10}{|l|}{ 344-U1380C- } \\
\hline $5 R-3,92-93$ & 470.22 & 2.816 & 0.614 & -1.84 & -1.01 & 0.70870 & 0.14 & 10.9 & 1.89 \\
\hline $8 R-2,91-92$ & 498.61 & 5.298 & 0.790 & -0.10 & -0.26 & 0.70888 & 0.13 & 5.5 & 3.78 \\
\hline $12 R-8,59-60$ & 543.65 & 12.878 & 0.753 & -0.82 & 2.31 & 0.70899 & 0.04 & 2.3 & 1.32 \\
\hline 16R-1, 136-137 & 575.16 & & & -2.41 & -4.12 & 0.70866 & 0.31 & 7.1 & 1.20 \\
\hline 17R-2, 117-118 & 587.20 & & & -1.77 & -2.25 & 0.70867 & 0.33 & 7.4 & 1.64 \\
\hline $20 \mathrm{R}-2,87-89$ & 614.22 & & & 0.24 & -2.53 & 0.70846 & 0.06 & 9.7 & 0.43 \\
\hline $23 \mathrm{R}-2,32-33$ & 643.49 & & & & & 0.70834 & 0.27 & 6.5 & 0.85 \\
\hline $31 \mathrm{R}-1,31-32$ & 690.61 & 7.589 & 0.801 & -1.16 & -5.00 & 0.70818 & 0.12 & 5.2 & 0.59 \\
\hline $33 R-2,32-34$ & 701.86 & & & & & 0.70814 & 0.40 & 6.4 & 0.80 \\
\hline $34 \mathrm{R}-2,90-91$ & 707.03 & 5.598 & 0.841 & -0.77 & -2.97 & 0.70872 & 0.12 & 7.4 & 1.30 \\
\hline $36 R-3,64-66$ & 717.94 & & & & & 0.70859 & 0.20 & 5.2 & 1.13 \\
\hline $39 R-1,72-73$ & 729.72 & & & & & 0.70849 & 0.24 & 5.3 & 1.02 \\
\hline $41 \mathrm{R}-1,50-52$ & 739.30 & & & 3.78 & -5.11 & 0.70854 & 0.07 & 13.7 & 0.21 \\
\hline $42 \mathrm{R}-1,30-31$ & 744.00 & & & 4.99 & -4.13 & 0.70860 & 0.04 & 13.8 & 0.27 \\
\hline $42 \mathrm{R}-1,30-31^{*}$ & 744.00 & & & 4.75 & -3.13 & 0.70863 & 0.05 & 10.7 & 0.40 \\
\hline $43 R-3,49-51$ & 751.84 & & & -0.71 & -5.04 & 0.70870 & 0.15 & 9.0 & 0.91 \\
\hline $47 R-3,79-81$ & 771.35 & 8.138 & 0.814 & -1.10 & -5.82 & 0.70797 & 0.42 & 6.6 & 0.48 \\
\hline $48 R-3,55-57$ & 776.24 & 2.99 & 0.607 & -2.62 & -6.35 & 0.70805 & 0.84 & 9.0 & 1.26 \\
\hline $52 \mathrm{R}-2,67-68$ & 795.97 & & & 4.85 & -4.25 & 0.70861 & 0.08 & 10.9 & 0.46 \\
\hline
\end{tabular}

* = duplicate sample. ${ }^{87} \mathrm{Sr} /{ }^{86} \mathrm{Sr}$ data normalized to NIST standard NBS-987. Repeated measurements yielded a mean value of $0.701245 \pm$ $0.000027\left(2 \sigma_{\text {mean }} ; N=115\right)$. PDB = Peedee belemnite, $\mathrm{SMOW}=$ standard mean ocean water. 